\title{
PENERAPAN KEBIJAKAN IZIN PEMANFAATAN AIR DAN ENERGI AIR DI TAMAN NASIONAL KERINCI SEBLAT DALAM MEWUJUDKAN PEMBANGUNAN BERWAWASAN LINGKUNGAN
}

\author{
Arif Wibowo, \\ Email: warief_85@yahoo.co.id \\ Mahasiswa Magister Ilmu Hukum Universitas Sebelas Maret \\ I Gusti Ayu Ketut Rachmi Handayani, Al. Sentot Sudarwanto \\ Email: ayu_igk@staff.uns.ac.id, alsentotsudarwanto@yahoo.com \\ Dosen Fakultas Hukum Universitas Sebelas Maret
}

\begin{abstract}
This paper aims to find out and analyze the implementation of regulation of water and water energy utilization in national park especially in Kerinci Seblat National Park. The implementation of the ministry regulation can be defined as an achievement of purposes, values and directed practices. This research uses the research method of empirical law or non-doctrinal in conducting the implementation towards the permit regulation of water and water energy utilization in National Park. The case study is conducted in the Great Hall of Kerinci Seblat National Park. In implementing the permit, the permit policy of water and water energy utilization has been conducted accordance with the regulation as well as the permit granting has been done thoroughly and calculated the enviromental needs. There are some obstacles faced in implementing the permit, so it needs synchronization with the related regulations, socialization, coordination among the local governments. In additional, it also needs clear timetable in the process of administrative and technical consideration as well as it needs evaluation monitoring and coaching to make the function of permit appropriate as the control and arrangement in the term of technical and legal certainty. The activities should observe the environmental impact and support the efforts in improving the society's prosperity and the quality of human life as well as realizing the environmental-based development.
\end{abstract}

Key words: The policy implementation; The Permit Regulation of Water and Water Energy Utilization; National Park; Environmental-based Development.

Artikel ini bertujuan untuk mengkaji dan menganalisis penerapan kebijakan izin pemanfaatan air dan energi air di taman nasional khusunya Taman Nasional Kerinci Seblat. Penerapan peraturan menteri tersebut dapat diartikan sebagai suatu pencapaian tujuan, nilai-nilai dan praktek-praktek yang terarah. Penelitian ini mengunakan metode penelitian hukum empiris atau non doktrinal dengan analisis data kualitatif dengan model interaktif, lokasi penelitian di Balai Besar Taman Nasional Kerinci Seblat. Dalam penerapan kebijakan izin pemanfaatan air dan energi air telah dilaksanakan sesuai dengan peraturan perundang-undangan, pemberian izin dilakukan dengan cermat dan memperhitungkan kepentingan lingkungan. Dalam pelaksanaan anya adanya kendala untuk itu, perlunya singkronisasi peraturan yang terkait, sosialisasi peraturan, upaya peningkatan koordiansi dengan pemerintah daerah, dan perlunya 
pengaturan tata waktu yang jelas dalam proses syarat administrasi dan pertimbangan teknis, serta perlunya pengawasan, evaluasi dan pembinaan agar sesuai fungsi perizinan sebagai penertib dan pengatur dilihat dari segi teknis dan kepastian hukum. Dalam kegiatan tersebut juga memperhatikan dampak lingkungan dan mendukung upaya peningkatan kesejahteraan masyarakat dan mutu kehidupan manusia serta mewujudkan pembangunan yang berwawasan lingkungan.

Kata Kunci : Penerapan kebijakan; Izin Pemanfaatan Air dan Energi Air; Taman Nasional; Pembangunan berwawasan lingkungan.

\section{A. Pendahuluan}

Penelitian ini berupaya untuk mengkaji dan menganalisis penerapan kebijakan peraturan izin pemafaatan air dan energi air di Taman Nasional Kerinci Seblat. Seperti kita ketahui bahwa sumber daya alam wajib dikelola secara bijaksana agar dapat dimanfaatkan secara berdaya guna, berhasil guna dan berkelanjutan, untuk kepentingan yang sebesar-besarnya bagi kemakmuran rakyat, baik generasi sekarang maupun generasi yang akan datang. Sumber daya alam memberikan dasar penghidupan manusia di seluruh dunia. Ketersediaan sumber daya alam baik hayati maupun non-hayati sangat terbatas, oleh karena itu pemanfaatannya baik sebagai modal alam maupun komoditas harus dilakukan secara bijaksana sesuai dengan karakteristiknya. (David Thomas,et.al. 2016).

Salah satu sumber daya alam di Indonesia adalah sumber daya air dan hutan. Seperti kita ketahui bahwa dalam konsep siklus hidrologi sumber daya air, hutan merupakan pengatur tata air (hidro-orologi) dan penyedia air bagi masyarakat di hulu maupun pengguna air lainnya dibagian hilir. Pemanfaatan air dari kawasan hutan telah banyak dilakukan oleh pemerintah, masyarakat, maupun pihak swasta baik untuk keperluan yang bersifat komersial maupun non komersial.(www.ekowisata.org./Perijinan/Pemanfaatan.air). Kebijakan konservasi alam dan lingkungan hidup diarahkan pada terjaminnya proses ekologi yang menunjang sistem penyangga kehidupan, terpeliharanya keanekaragaman sumber genetik dan tipe-tipe ekosistemnya serta terkendalinya pemanfaatan sumber daya alam hayati untuk menjamin kelestarian manfaatnya. (Alam Setia Zain, 1998:24).

Sebagai salah satu kawasan konservasi Taman Nasional memiliki keanekaragaman hayati, Berdasarkan Undang-Undang No. 05 Tahun 1990 Tentang KSDAE Pasal 1 Nomor (14) pengertian Taman Nasional adalah kawasan 
pelestarian alam yang mempunyai ekosistem asli, dikelola dengan sistem zonasi yang dimanfaatkan untuk tujuan penelitian, ilmu pengetahuan, pendidikan, menunjang budidaya, pariwisata, dan rekreasi. Selanjutnya dalam Undang-Undang No 5 Tahun 1990, Pasal 33 ayat (3) berbunyi "Setiap orang dilarang melakukan kegiatan yang tidak sesuai dengan fungsi zona pemanfaatan lain dari Taman Nasional, Taman hutan raya, dan Taman wisata alam”. Selanjutnaya Pasal 40 ayat (2) dengan ancaman hukuman yaitu "Barang siapa dengan sengaja melanggar ketentuan dimaksud Pasal 21 Ayat 1 dan Pasal 21 Ayat 2 serta, Pasal 33 Ayat 3, dipidana penjara paling lama 5 (lima) tahun dan denda paling banyak seratus juta rupiah.

Atas dasar pelarangan tersebut Pemerintah mengatur fungsi perizinan pemanfaatan kawasan konservasi dalam Peraturan Pemerintah dan peraturan dibawahnya. Pemanfaatan Taman Nasional menurut Peraturan Pemerintah No. 28 Tahun 2011 Pasal 35 yaitu Taman Nasional dapat dimanfaatkan untuk kegiatan:

a. Penelitian dan pengembangan ilmu pengetahuan;

b. Pendidikan dan peningkatan kesadartahuan konservasi alam;

c. Penyimpanan dan /atau penyerapan karbon, pemanfaatan air serta energi air, panas dan angin serta wisata alam;

d. Pemanfaatan tumbuhan dan satwa liar;

e. Pemanfaat sumber plasmah nutfah untuk penunjang budidaya;

f. Pemanfaatan tradisional oleh masyarakat setempat.

Taman Nasional Kerinci Seblat merupakan Kawasan Pelestarian Alam yang berada di Pulau Sumatera memiliki luas 1.389.509,867 Ha. Taman Nasional Ini pertama kali diumumkan sebagai salah satu calon taman nasional melalui Surat Keputusan Menteri Pertanian Nomor : 736/Mentan/X/1982 tanggal 10 Oktober 1982. Kawasan ini merupakan gabungan dari beberapa kawasan Cagar Alam, Suaka Margasatwa, Taman Wisata dan Hutan Lindung. Kemudian berdasarkan Surat Keputusan Menteri Kehutanan No. 192/Kpts-II/1996 tanggal 1 Mei 1996 menetapkan luas kawasan TNKS menjadi 1.386.000 Ha. Kemudian muncul lagi Keputusan Menteri Kehutanan dan Perkebunan No. 901/Kpts-II/1999 yang 
menetapkan luas TNKS menjadi 1.375.389,867 Ha.(www.tfca.org.taman-nasionalkerinci-seblat). Balai Besar Taman Nasional Kerinci Seblat terletak di 4 (empat) Provinsi yaitu Jambi, Sumatera Barat, Bengkulu dan Sumatera Selatan.

Tantangan yang di hadapi dengan terbitnya payung hukum pemanfaatan jasa lingkungan air adalah, sosialisasi, pelaksanaan dan pengawasannya, penyebarluasan peraturan tersebut kepada para pemanfaat air baik komersil maupun non komersil. Sehingga kegiatan pemanfaatan jasa lingkungan air berjalan sesuai aturan tertib dan memberikan manfaat bagi kawasan konservasi. Potensi pemanfaatan air dan energi air sering disebut sebagai pemanfaatan jasa lingkungan air yang telah diatur berdasarkan peraturan perundang-undang. Dalam pelaksaaan pengelolaan pemanfaatan potensi jasa lingkungan air di kawasan TNKS dapat memberikan kepastian hukum dalam pemanfaatannya.(www.mongabay.co.id/keutuhan tnks).

Ketidak singkronan dalam pelaksanaan Peraturan Menteri Kehutanan No. P.64/Menhut-II/2013 tentang pemanfaatan air dan energi air di Suaka Margasatwa, Taman Nasional, Taman Hutan Raya dan Taman dan Taman Wisata Alam. Dalam syarat administrasi untuk izin Non komersil dan komsersil skala Mikro serta Kecil pemanfaatan air dan energi air tidak mensyaratkan izin lingkungan akan tetapi Izin Pemanfaatan air dan energi air skala menengah dan besar mensyaratkan dalam syarat administrasi persetujuan prinsip pemohon wajib menyusun dan menyampaikan UKL-UPL. Sehingga Permenhut P.64/Menhut-II/2013 juga harus berdasarkan Peraturan Pemerintah No. 27 Tahun 2012 tentang izin lingkungan dan Peraturan Menteri Lingkungan Hidup No. 13 Tahun 2010 tentang UKL-UPL dan SPPL, serta Peraturan Menteri Lingkungan Hidup No.05 Tahun 2012 tentang Kegiatan Usaha Wajib Amdal. Izin lingkungan tersebut sebagi bentuk upaya dalam melestarikan lingkungan khususnya kawasan konservasi. Untuk itu ketidak singkronan peraturan menimbulkan hambatan dalam pemanfaatan air dan energi air yang berwawasan lingkungan.

Pemanfaatan air dan energi air berada di dalam zona pemanfaatan Taman Nasional Kerinci Seblat mempunyai potensi yang sangat besar. Meningkatnya jumlah penduduk disekitar kawasan taman nasional, yang berbanding lurus dengan peningkatan kebutuhan akan sumberdaya air sehingga fungsi zona pemanfaatan 
pada taman nasional dapat dimanfaat yang sebesar-besarnya untuk kesejahteraan masyarakat, dengan cara tetap menjaga kelestarian sumber daya alam hayati dari kerusakan lingkungan. Berdasarkan uraian diatas artikel ini hendak membahas bagaimana implementasi kebijakan peraturan izin pemanfaatan air dan energi air di Taman Nasional Kerinci Seblat dan kendala dalam penerapan kebijakan peraturan izin pemanfaatan air dan energy air dalam mewujudkan pembangunan berwawasan lingkungan.

\section{B. Metode Penelitian}

Penelitian ini merupakan penelitian hukum empiris deskriptif analisis, Penelitian hukum empiris (Non Doktrinal) merupakan salah satu jenis penelitian hukum yang menganalisis dan kajian bekerjanya hukum di dalam masyarakat, bekerjanya hukum dalam masyarakat dapat dikaji dari tingkatan efektivitas hukum, kepatuhan terhadap hukum peranan lembaga, atau institusi hukum di dalam menegakan hukum, Implementasi aturan hukum terhadap masalah sosial tertentu atau sebaliknya pengaruh masalah sosial terhadap aturan hukum.(Salim HS.dan Erlis Septiana, 2013:20). Lokasi penelitian adalah Balai Besar Taman Nasioanal Kerinci Seblat di Provinsi Jambi, data yang dipergunakan data primer dan data skunder. Sumber data primer diperoleh dari wawancara Kepala Balai Besar TNKS, Kepala Bidang Teknis Konservasi, Kepal Seksi Pemanfaatan dan Pelayanan dan Tokoh masyarakat sekitar kawasan Taman Nasional Kerinci Seblat. Data skunder diperoleh dari peraturan perundang-undangan yang terkait. Teknik pengumpulan data primer menggunakan wawancara dan dan data sekunder menggunakan studi kepustakaan. Model analisis data kualitatif yang digunakan adalah model interaktif.

\section{Hasil penelitian Dan Pembahasan}

\section{Penerapan Kebijakan Izin Pemanfaatan Air dan Energi Air di Taman}

Nasional Kerinci Seblat dalam Mewujudkan Pembangunan berwawasan

\section{Lingkungan}

Peraturan izin pemanfaatan air dan energi air di kawasan konservasi merupakan kebijakan secara umum dibidang perizinan di taman nasional. Peraturan pemanfaatan air dan energi air di kawasan taman nasional termasuk kebijakan 
publik ekologis karena menyangkut kepentingan umum (bukan hanya kepentingan pemerintah dan pengusaha). Secara teoritis Implementasi Peraturan Izin Pemanfaatan Air dan Energi air di taman Nasional merupakan hasil dari sebuah kebijakan publik berhubungan dengan apa yang dipilih pemerintah untuk dilakukan juga tidak dilakukan. (Thomas R.Dye dalam Joko Widodo, 2009:13) Menurut Harold dan D. Lesswell dan Abraham Kaplan, kebijakan adalah "a projected program of goal values and practices".(Rhiti \& Pudyatmoko, 2016). Ketika pemerintah membuat kebijakan pemanfaatan air dan energi air di taman nasional tentu ada maksud dan tujuan yang hendak dicapai dengan menjunjung nilai-nilai konservasi dan kelestarian fungsi ekologis bagi kemaslahatan bersama.

Menurut Barclay dan Birkland hubungan antara hukum dan kebijakan publik yang pertama dan mendasar adalah kebijakan publik umumnya harus didelegasikan dalam bentuk hukum, dan pada dasarnya sebuah hukum adalah dari hasil kebijakan publik. Dari pemahaman dasar ini kita dapat melihat keterkaitan diantara keduanya sangat jelas. (Esmi wirassih, 2005:132). Salah satu prinsip dalam negara hukum adalah wetmatigheid van bestuur, atau pemerintah berdasarkan peraturan perundang-undangan, dengan kata lain setiap tindakan hukum pemerintah baik dalam menjalankan fungsi pengaturan maupun fungsi pelayanan, harus didasarkan pada wewenang yang diberikan oleh peraturan dan perundang-undangan yang berlaku.Untuk dapat melaksakan dan menegakkan ketentuan hukum positif perlu wewenang, tanpa wewenag tidak dapat dibuat keputusan yuridis yang bersifat kongkret. (AndrianSutedi, 2015:179)

Balai Besar Taman Nasional Kerinci Seblat yang merupakan kawasan konservasi memunpunyai potensi sumber daya air yang melimpah karena berada pada hulu air 3 (tiga) DAS utama Sumatera yaitu DAS Batanghari berada di Provinsi Jambi, DAS Pantai Barat di Bekulu dan Sumatera Barat, DAS Musi di Sumatera Selatan. Sepanjang DAS (daerah aliran Sungai) mampu mengairi sepuluh juta Ha. Lahan Pertanian di sepanjang DAS, merupakan sumber air bersih bagi lima juta penduduk disekitar Kawasan TNKS, mempunyai potensi PLTMH, PLTA dan PDAM, potensi industri air minum dalam kemasan, serta mempunyai objek daya tarik wisata alam.(Statistik BBTNKS: 2017). Konsep yang diterapkan dalam 
pengelolaaan taman nasional adalah pengelolaan kawasan berbasis ekosistem. Pelaksanaan prinsip-prinsip pengelolaan berbasis ekosistem memerlukan adanya kerjasama atau kolaboratif seluruh pemangku kepentingan, sehingga memungkinkan tercapainya pihak-pihak yang berkepentingan dalam merumuskan keseimbangan fungsi- fungsi ekologis, ekonomis dan sosial dalam suatu ekosistem hutan. (Faiqotul Falah: 2013)

Berdasarkan Undang-Undang No. 32 Tahun 2009 Tentang Pengelolaan dan Perlindungan Lingkungan Hidup Pasal 1 ayat (3) dijelaskan bahwa pembangunan berkelanjutan adalah upaya sadar dan terencana dan memadukan aspek lingkungan hidup, sosial, dan ekonomi, kedalam strategi pembangunan untuk menjamin keutuhan lingkungan hidup serta keselamatan, kesejahteraan dan mutu hidup generasi masa kini dan generasi masa depan. Dengan ciri berkelanjutan pembangunan mengandung arti perbaikan mutu kehidupan manusia dengan tetap berusaha tidak melampaui kemampuan ekosistem untuk mendukungnya. Pembangunan berkelanjutan adalah suatu proses pembangunan yang menyerasikan pemanfaatan sumber daya alam dan sumber daya manusia dalam pembangunan. (Syahrul Machmud, 2012:67).

Christina Voight menyatakan sustainable development bukan hanya permasalahan mengenai isu lingkungan saja hal yang terpenting yaitu adanya integrasi dan keadilan transgenerasi yang intinya keadilan yang diterima antara generasi sekarang dengan generasi yang akan datang. Generasi sekarang harus mampu memenuhi kebutuhannya dengan dengan tetap menjaga lingkungannya agar tetap berlanjut pemanfaatanya untuk masa depan. Generasi mendatang tidak akam mampu memenuhi kebutuhanya apabila sumber daya alam sudah habis disaat sekarang tanpa adanya kesadaran untuk menjaga, memelihara dan memastikan tetap berkelanjutan ekosistem penyokong sumber daya alam yang ada di alam ini. Sebuah ketidak adilan bagi generasi mendatang ketika ekosistem telah mengalami kemunduran dan tidak menyisakan banyak hal untuk mereka. Berdasarkan hal tersebut Christina Voight berpendapat bahwa; "Sustainable development is a multifaceted concept covering integration of economic and social and 
environmental concern, equity and justice between generations and within the present generation"(Christina Voight, 2009;113)

Pemanfaatan air dan energi air di TNKS dilaksanakan berdasarkan rencana pengelolaan dan hasil inventerisasi sumberdaya air yang berada dikawasan Taman Nasional Kerinci Seblat.

Pada umumnya permohonan izin harus menempuh prosedur tertentu yang ditentukan oleh pemerintah selaku pemberi izin. Di samping harus menempuh prosedur tertentu, pemohon izin juga harus memenuhi persyaratan-persyaratan tertentu yang ditentukan secara sepihak oleh pemerintah atau pemberi izin. Prosedur dan persyaratan perinzinan itu berbeda- beda tergantung jenis izin, tujuan izin dan instansi pemberi izin.

Gambar. 1. Alur Proses Izin Pemanfaatan air dan energi Air pada Balai Besar TNKS 


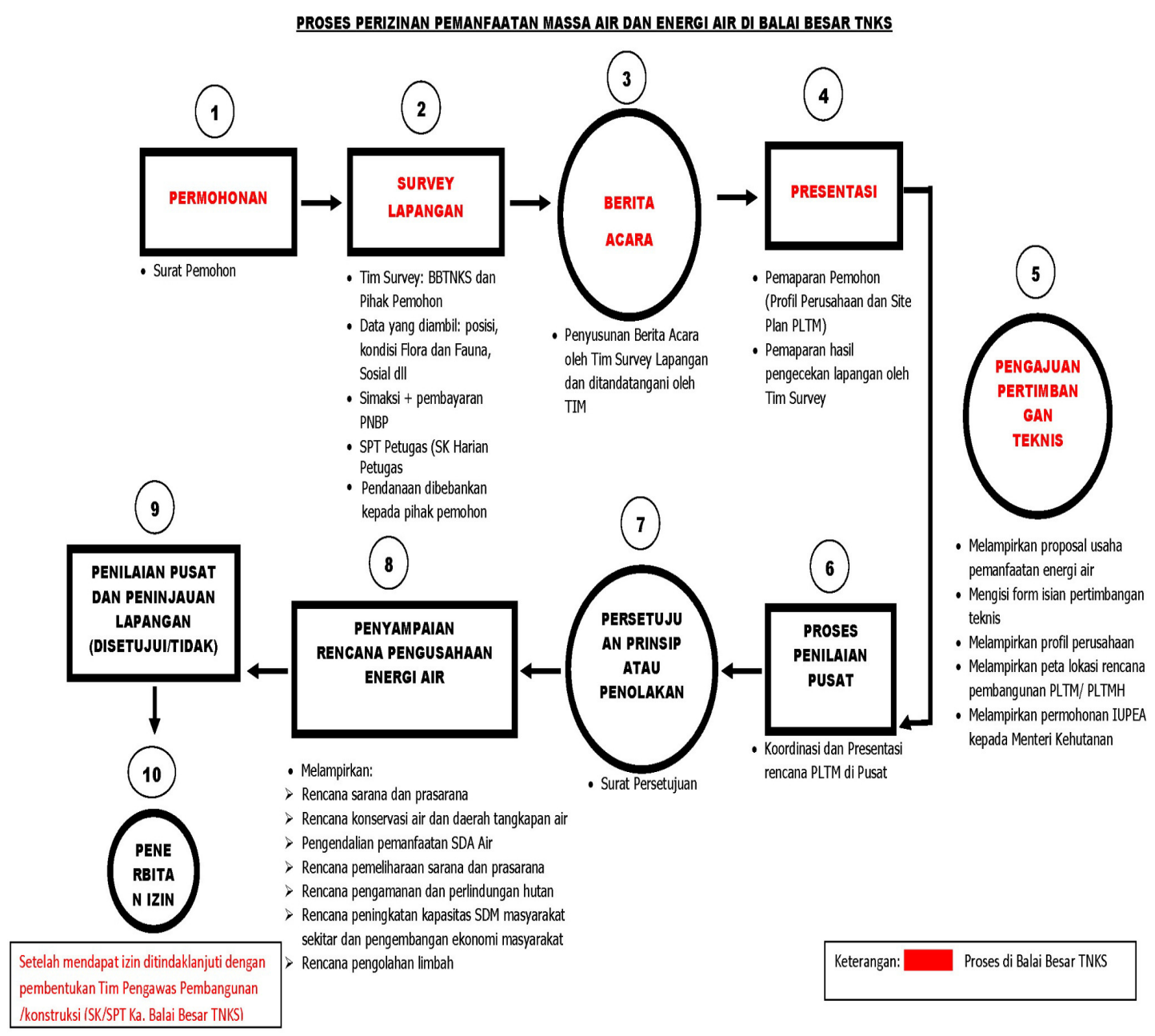

Data proses berdasarkan penerapan kebijakan perizinan yang dikeluarkan dalam pemanfaatan air dan energi air di sekitar kawasan TNKS mengingat potensi yang sangat besar khususnya sumber daya air di TNKS. Adapun kelompok masyarakat dan perusahaan atau pihak ketiga yang telah melakukan permohonan pemanfaatan air sebagai berikut :

Tabel.1. Usulan Permohonan Pemanfaatan Air dan Energi Air. 2010-2015

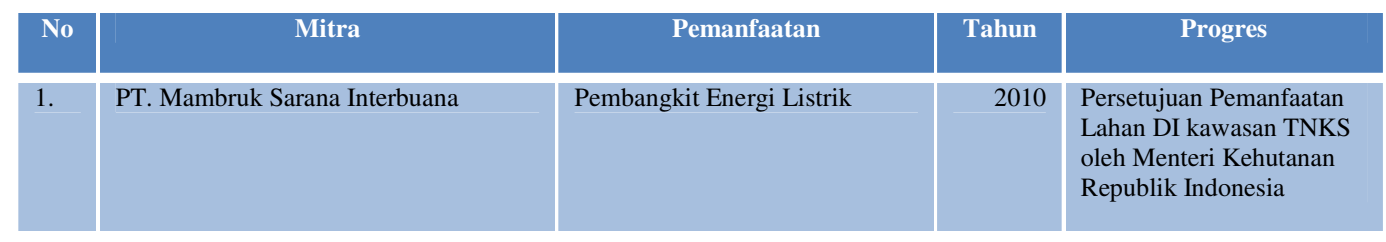

Jurnal Hukum Dan Pembangunan Ekonomi (Vol.6 No.2) 


\begin{tabular}{|c|c|c|c|c|}
\hline 2. & PT. Bergonia Pratama & Pembangkit Energi Listrik & 2010 & Pengecekan Lapangan \\
\hline 3. & Masyarakat Selupu Rejang & Sumber Air Bersih & 2010 & $\begin{array}{l}\text { MoU (penyampaian } \\
\text { penyesuaian P.64) }\end{array}$ \\
\hline 4. & PDAM Kab. Pesisir Selatan & Sumber Air Baku & 2012 & $\begin{array}{l}\text { Persentasi Hasil } \\
\text { Pengecekan Lapangan }\end{array}$ \\
\hline 5. & PT. Exsabenar Cipta Karya & Pembangkit Energi Listrik & 2012 & Pengecekan Lapangan \\
\hline 6. & PT. Raja Daya Primamega Utama & Pembangkit Energi Listrik & 2012 & $\begin{array}{l}\text { Permohonan (surat } \\
\text { melakukan pengecekan } \\
\text { lapangan) }\end{array}$ \\
\hline 7. & PT. Nawakara Energi Bonjol & Pembangkit Energi Listrik & 2012 & Pengecekan Lapangan \\
\hline 8. & Pemda Kab. Kerinci & Pembangkit Energi Listrik & 2012 & Pengecekan Lapangan \\
\hline 9. & PT. Tirta Energi Lestari & Pembangkit Energi Listrik & 2013 & $\begin{array}{l}\text { Permohonan } \\
\text { (penyampaian pengecekan } \\
\text { lapangan) }\end{array}$ \\
\hline 10. & PT. Lebong Berkat Energi & Pembangkit Energi Listrik & 2013 & $\begin{array}{l}\text { Persentasi Hasil } \\
\text { Pengecekan Lapangan }\end{array}$ \\
\hline 11. & PT. Lebong Sugih Energi & Pembangkit Energi Listrik & 2013 & Pengecekan Lapangan \\
\hline 12. & PT. Bumi Sugih Energi & Pembangkit Energi Listrik & 2013 & Pengecekan Lapangan \\
\hline 13. & PT. Sungai Garam* & Pembangkit Energi Listrik & 2014 & Pertimbangan Teknis \\
\hline 14. & PT. Batang Bangko Hidro Energi & Pembangkit Energi Listrik & 2014 & Pengecekan Lapangan \\
\hline 15. & PT. Adhi Karya & Pembangkit Energi Listrik & 2014 & $\begin{array}{l}\text { Persentasi Hasil } \\
\text { Pengecekan Lapangan }\end{array}$ \\
\hline 16. & PT. Dempo Hidro Energi & Pembangkit Energi Listrik & 2014 & Pengecekan Lapangan \\
\hline 17. & PT. Kamiko Nano Sigintir Utama & Pembangkit Energi Listrik & 2014 & Pengecekan Lapangan \\
\hline 18. & PT. Kerinci Merangin Hidro & Pembangkit Energi Listrik & 2014 & Pengecekan Lapangan \\
\hline 19. & SPN Polda Bengkulu & Sumber Air & 2015 & IPA \\
\hline 20. & PT. Saga Sangir Selaras & Pembangkit Energi Listrik & 2015 & Pengecekan Lapangan \\
\hline 21. & PT. Bangun Tirta Lestari & Pembangkit Energi Listrik & 2015 & $\begin{array}{l}\text { MoU Perlindungan, } \\
\text { Pelestarian dan } \\
\text { Pemanfaatan Sumberdaya } \\
\text { air dan Ekosistemnya } \\
\text { (sumber air berasal dari } \\
\text { kawasan TNKS) }\end{array}$ \\
\hline 22 & PT. Inti Alam Lestari* & Pembangkit Energi Listrik & 2015 & Persetuan Prinsip \\
\hline 23 & PDAM Tirta Sakti Kerinci & Sumber air & 2015 & IUPA \\
\hline
\end{tabular}

Sumber data : BBTNKS Tahun 2017

Tabel.2. Usulan Permohonan Pemanfaatan Air dan Energi Air. 2016-2017 


\begin{tabular}{|c|c|c|c|c|}
\hline 24 & PT. Brantas Cakrawala Energi & Pembangkit Energi Listrik & 2016 & IUPEA \\
\hline 25 & PT. Cibodas Hidro Energi & Pembangkit Energi Listrik & 2016 & $\begin{array}{l}\text { Persentasi Hasil } \\
\text { Pengecekan Lapangan }\end{array}$ \\
\hline 26 & PT. Energi Baru Terbarukan* & Pembangkit Energi Listrik & 2016 & Pertimbangan Teknis \\
\hline 27 & PT. Sinerji Tenaga Air* & Pembangkit Energi Listrik & 2016 & Pertimbangan Teknis \\
\hline 28 & PT. Gadang Hidro Energi & Pembangkit Energi Listrik & 2016 & Pertimbangan Teknis \\
\hline 29 & PDAM Rejang Lebong & Massa/ Sumber Air & 2017 & Permohonan \\
\hline 30 & PGE Tambang Sawah & Geotermal/ & 2017 & Survey Lapangan \\
\hline 31 & PT. Abipraya Nusantara* & Pembangkit Energi Listrik & 2017 & Pertimbangan Teknis \\
\hline 32 & PT. Energi Taratak Tempatih & Pembangkit Energi Listrik & 2017 & Survey lapangan \\
\hline 33 & PT. Ketahun Hidro Energi & Pembangkit Energi Listrik & 2017 & $\begin{array}{l}\text { Persentasi hasil cek } \\
\text { lapangan }\end{array}$ \\
\hline 34 & PDAM Merangin & Massa / Sumber Air & 2017 & Permohonan \\
\hline 35 & PT PAUL Master Energy Investment & Pembangkit Energi Listrik & 2017 & Permohonan \\
\hline 36 & PT. Pemanfaatan Energi Air & Pembangkit Energi Listrik & 2017 & Pertimbangan Teknis \\
\hline
\end{tabular}

Sumber : BBTNKS Tahun 2017

Berdasarkan Data tersebut diatas proses perizinan ada yang telah selesai ada pula yang belum selesai atau dalam proses. Dapat digambarkan dalam grafik. Sebagai Berikut :

Gambar. 2. Grafik proses Kemajuan Perizinan Tahun 2010-2017

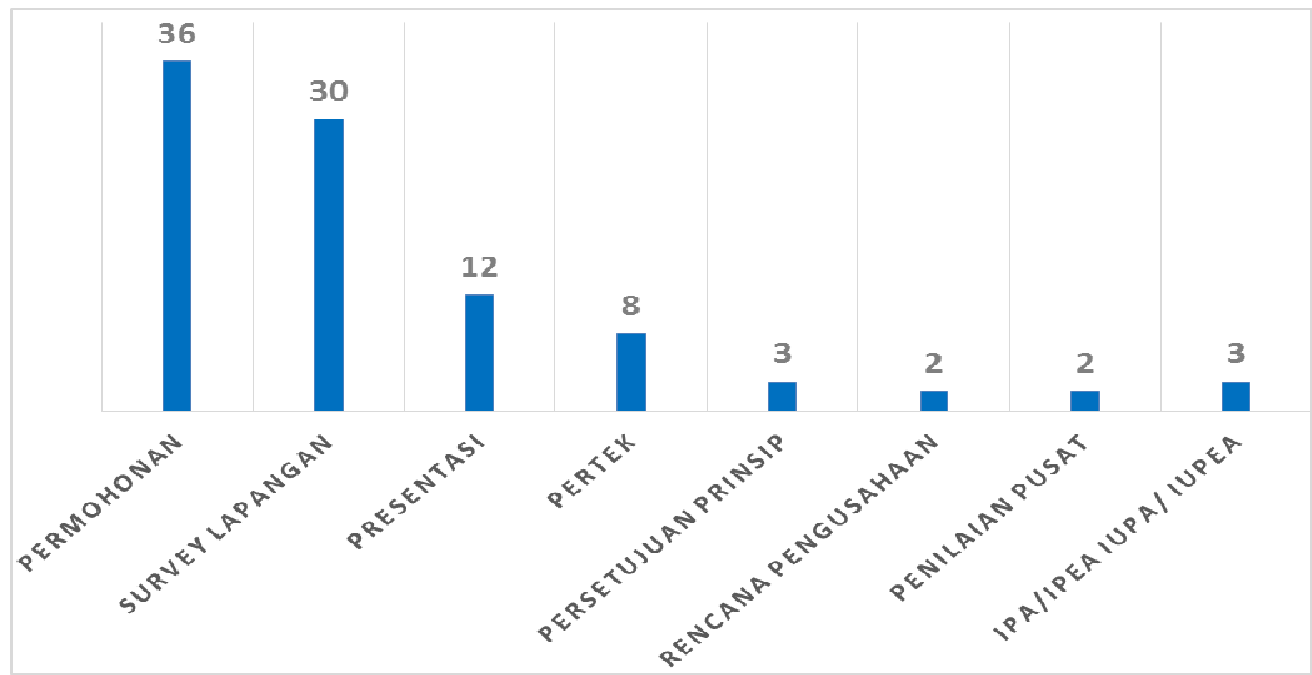

Sumber : BBTNKS Tahun 2017

Berdasarkan syarat dan alur perizinan tersebut penulis menganalisis dalam syarat administrasi cukup jelas untuk dilaksanakan bagi kelompok masyarakat 
maupun instansi di sekitar kawasan pemanfaatan air dan energi air di TNKS. Dalam proses pembanguan yang dilakukan oleh bangsa Indonesia harus diselenggarakan berdasarkan prinsip pembangunan berkelanjutan dan berwawasan lingkungan sesuai dengan amanah Pasal 33 ayat (4) Undang-Undang Dasar 1945. Pemanfaatan sumberdaya alam menjadi modal dasar pembangunan di Indonesia saat ini dan masih diandal dimasa yang akan datang. Untuk itu pemanfaatan air dan energi air dalam kawasan TNKS haruslah berdasarkan pembangunan berwawasan lingkungan

Berdasarkan Pasal 34 Ayat (1) Undang-Undang Nomor 32 Tahun 2009 tentang PPLH mengatur bahwa Setiap Usaha atau dan atau kegiatan yang tidak dalam termasuk kriteria wajib amdal wajib UKL-UPL. Berdasarkan Pasal 35 Ayat (1) Undang-Unadang Nomor 32 Tahun 2009 Tentang PPLH mengatur pula bahwa usaha dan atau kegiatan yang tidak wajib dilengkapi UKL-UPL wajib membuat surat pernyataan kesanggupan pengelolaan dan pemantauan lingkungan hidup(SPPL). Sedangkan ayat (2) menyatakan Penetapan jenis usaha dan/atau kegiatan sebagaimana dilakukan berdasarkan kriteria tidak termasuk dalam kategori berdampak penting atau kegiatan wajib amdal Pasal 23 ayat (1); dan kegiatan usaha mikro dan kecil. Telah diatur dalam Peraturan Menteri Lingkungan Hidup Nomor 13 Tahun 2010 Tentang UKL-UPL dan SPPL.

Pelaksanaan izin Pemanfatan air dan energi air dikawasan taman nasional kerinci seblat telah dilakukan berdasarkan Peraturan Menteri No P.64/MebhutII/2013, Khususnya pada perinzinan pemanfatan air dan energi air Non Komersil telah sesuai dengan peraturan perundangan yang terkait.(Hasil wawancara Bapak Rusman Kepala Bidang Teknis Konservasi Balai Besar TNKS, 2017) Menurut data yang diperoleh dari Balai Besar Taman Nasional Kerinci Seblat tentang Perizinan pemanfatan air dan energi air pemohon yang sudah berizin anatar lain :

Tabel.2 Perizinan Pemanfaatan air dan Energi air

\begin{tabular}{|c|c|c|c|c|c|}
\hline No & Mitra & Pemanfaatan & Tahun & Progres & Keterangan \\
\hline 1. & PDAM Tirta Sakti Kab. Kerinci & Sumber Air Baku & 2015 & IUPA & UKL-UPL \\
\hline 2. & Polda Bengkulu (SPN Bukit Kaba) & Sumber Air Baku & 2015 & IPA & - \\
\hline 3. & PT. Brantas Cakrawala Energi & Pembangkit Energi Listrik & 2016 & IUPEA & AMDAL \\
\hline
\end{tabular}
Sumber Data : BBTNKS. Tahun 2017 
Dari data tersebut diatas masih minimnya izin yang dikeluarkan dalam pemanfaatan air dan energi air di sekitar kawasan TNKS mengingat potensi yang sangat besar. (laporan Statistik BBTNKS 2016). Bedasarkan Tabel diatas Izin pemanfaatan air dan energi air pada prakteknya dilapang telah mewujudkan pembangunan berwawasan lingkungan dengan menetapan syarat izin lingkung baik UKL-UPL dan AMDAL akan tetapi di Peraturan Menteri No P.64/Mebhut-II/2013. Izin lingkungan merupakan syarat persetujan prinsip yang dikeluarkan Menteri untuk skala menengah dan Skala Besar hanya sampai pada UKL-UPL.

Dalam pelaksanaan pemberian izin wewenang Balai Besar TNKS pada Izin Pemanfaatan air dan Energi air untuk non komersil sebagai subjek pemberi Izin. Izin pemanfaaan air (IPA) meliputi Izin pemanfaatan air untuk keperluan pemenuhan rumah tangga dan sosial dan Izin Pemanfaatan energi air (IPEA) untuk pembangunan listrik mikrohidro bagi kebutuhan rumah tangga dan sosial yang dikelola oleh kelompok masyarakat. Dalam hal ini Permohonan izin yang telah diterima sampai sekarang ini yaitu SPN Bukit Kaba Polda Bengkulu. Wewenang Balai Besar Taman Nasional Kerinci Seblat pada Izin Usaha Pemanfaatan Air dan Energi air untuk komersil sebagai Objek yaitu sampai dalam bentuk pertimbangan teknis, sebagai salah satu syarat untuk diterbitkan izin, wewenang pemberian izin tetap dilakukan oleh Menteri Lingkungan Hidup dan Kehutanan.(Hasil wawancara Bapak M. Arief Toengkagie Kepala Balai Besar TNKS, 2017)

Mengingat kenyataan bahwa pembangunan membawa dampak bagi sumber daya alam dan lingkungan maka perlu harmonisasi antara pembangunan dan lingkungan hidup. Pembangunan akan selalu membawa perubahan yang diharapkan adalah perubahan yang baik dan positif. Konsep pembangunan di Indonesia adalah pembangunan yang berkelanjutan yaitu pemenuhan kebutuhan generasi masa kini tanpa mengorbankan kebutuhan generasi yang mendatang atau dengan kata lain pembangunan diharapkan selaras dengan konsep pelestarian lingkungan.(Henry Bastaman, 2015)

Pemerintah sebagai penyelenggara negara yang ikut serta dalam rangka perlindungan dan pengelolaan lingkungan hidup mewajibkan izin lingkungan (environmental licence) kepada setiap rencana usaha yang dapat menimbulkan 
dampak kerusakan terhadap lingkungan hidup. Perizinan lingkungan adalah sarana yuridis administrasi untuk mencegah dan menanggualangi (pengendalian) pencemaran lingkungan. (Samsul wahidin, 2014:14) Terkait izin lingkungan pemerintah mengeluarkan Peraturan Pemerintah nomor 27 Tahun 2012 tentang Izin Lingkungan. Menurut Pasal I Angka (1) Izin Lingkungan adalah izin yang diberikan kepada setiap orang yang melakukan usaha dan/atau kegiatan wajib AMDAL atau UKL-UPL.dalam rangka perlindungan dan pengelolaan lingkungan hidup sebagai persyaratan untuk memperoleh izin usaha dan/atau kegiatan.

Pada perspetif administrasi izin lingkungan menjadi salah satu syarat penerbitan izin usaha dan/atau kegiatan di Indonesia. Hal ini menjadi dasar pengelolaan dan perlindungan lingkungan hidup agar tetap menjadi pedoman pokok untuk menghindarkan pengelolaan yang tidak bertanggung jawab. Selain itu izin lingkungan bisa menjadi penyaring suatu usaha agar memenuhi tiga persyaratan pembangunan berkelanjutan, yaitu menguntungkan secara ekonomi, diterima secara sosial dan ramah lingkungan. (Samsul wahidin, 2014:61-62). Pemanfaatan air di zona pemanfaatan taman nasional merupakan bentuk suatu pembangunan sektor kehidupan. Dalam aturan izin pemanfaatan air Non Komersil secara administrasi tidak ada izin lingkungan dan surat pernyataaan kesanggupan pengelolaan dan pemantauan lingkungan hidup (SPPL) sebagai syarat administrasi agar dalam mewujudkan pembangunan yang berwawasan lingungan.

Tolak ukur untuk menetukan apakah suatu kegiatan wajib Amdal atau UKLUPL ditentukan dalam Pasal 22 ayat (2) serta Pasal 34 dan 35 (yang ditindaklanjuti dengan Permen No.5 Tahun 2012 tentang kegiatan yang wajib Amdal dan Permen LH No.13 Tahun 2010 tentang UKL-UPL dan SPPL). Untuk itu Perizinan Pemanfaatan air dan energi air di taman nasional juga memperhatikan ekologis dengan kata lain perizinan tidak berhenti pada sekedar kebijakan melainkan konsistensi pelaksanaan dan pengawasan serta singkronisasi antara peraturan izin yang satu dengan yang lain, dan saling menguatkan karena manfaat kawasan konservasi khususnya taman nasional sebagai penyedia jasa lingkungan air dan pemanfaatanya tetap konsisten untuk menjaga keseimbangan ekologis serta kelestarian kawasan hutan konservasi 
Dalam aturan izin pemanfaatan air Komersil untuk usaha skala Mikro dan usaha skala kecil secara administarsi tidak adanya izin lingkungan atau surat pernyataaan kesanggupan pengelolaan dan pemantauan lingkungan hidup akan tetapi dalam rencana pengusahaan pemanfaatan air dan energi air pihak pemohon diharuskan membuat rencana pengolahan limbah. Akan tetapi dalam praktenya dilapangan Pihak kementerian LHK mewajibkan agar pemohon untuk menyusun dan menyampaikan UKL-UPL. Untuk itu syarat administrasi perlu juga didasarkan pada Peraturan Menteri Negara Lingkungan Hidup Nomor 05 Tahun 2012 Tentang Jenis rencana Usaha dan atau kegiatan yang wajib memiliki AMDAL.

Untuk mewujudkan pembangunan berwawasan lingkungan dalam Peraturan Menteri Kehutanan No. P.64/Menhut-II/2013 tentang pemanfatan air dan energi air yang mengatur perizinan tersebut. Berdasarkan Pasal 31 huruf (c) Persetujuan prinsip untuk usaha skala menengah dan usaha skala Besar tersebut mensyaratkan pemohon hanya menyusun dan menyampaikan UKL-UPL. Menurut pendapat peneliti setiap izin usaha/dan atau kegiatan harus mempunyai Izin Lingkungan yaitu UKL-UPL dan AMDAL. Jadi Permenhut No P.64 Tahun 2013 dalam syarat tidak hanya di batasi hanya UKL-UPL tetapi seharusnya didasarkan pada Peraturan Pemerintah No. 27 tahun 2012 Tentang Izin Lingkungan.

\section{Kendala dalam penerapan peraturan izin pemanfaatan air dan energi air dalam mewujudkan pembangunan berwawasan lingkungan.}

Hukum Perizinanan adalah bagian dari hukum adminstrasi negara, adapun yang dimaksud dengan perizinan adalah melakukan perbuatan atau usaha yang sifatnya sepihak yang berada di bidang hukum publik yang berdasarkan wewenang tertentu yang berupa penetapan dari permohonan seseorang maupun badan hukum terhadap masalah yang dimohonkan. (Sjachran basah, 1995:195) Menurut Spelt dan Ten Berge izin merupakan suatu persetujuan dari penguasa berdasarkan UU atau peraturan pemerintah, untuk dalam keadaan tertentu menyimpang dari ketentuan larangan perundang-undangan.(N.M, Spelt \& B.J. Mten Berge, 1993:2-3)

Izin memperoleh kekuatan normatifnya hanya dari pemerintah dan karenanya juga diawasi oleh pemerintah sebagai pemberi izin jadi pemerintah merupakan agen utama dalam hal perizinan sekaligus aktor yang berpotensi mengubah yang tidak 
boleh menjadi boleh dan yang sudah di izinkan bias saja dicabut kembali izinnya. Spelt dan Ten Berge berpendapat motif-motif untuk menggunakan sistem izin dapat berupa: keinginan mengarahkan (mengendalikan-“sturen”) aktivitas-aktivitas tertentu, mencegah bahaya bagi lingkungan, keinginan untuk melindungi obyekobyek tertentu, hendak membagi benda-benda yang sedikit dan pengarahan dengan menyeleksi orang-orang dan aktivitas-aktifitas. (N.M,Spelt\&B.J.MtenBerge, 1993:4)

Dalam kaitanya dengan izin pemanfaatan air dan energi air di Taman Nasional yang merupakan kawasan konservasi motifnya untuk menjamin pemanfaatan air dan energi air memenuhi aspek ekonomi, sosial, lingkungan dan keadilan generasi sekarang dan yang akan datang. Tujuannya ialah untuk mengatur pemanfaatan air berupa massa air yang ada di permukaan tanah dan diatas permukaan tanah dan pemanfaatan energi air berupa jasa aliran air yang terdapat di pemukaan tanah di kawasan suaka margasatwa, taman nasional taman hutan raya dan taman wisata alam dengan tetap mejaga kelestarian kawasan. Izin mempunya urgensi tertentu yaitu sebagai (legal base), instrument untuk menjamin kepastian hukum, sebagai instrument untuk melindungi kepentingan dan sebagai alat bukti dalam hal ada klaim. Peraturan Menteri Kehutanan No P.64/Menhut-II/2013 Tentang Pemanfaatan air dan energi air kawasan suaka margasatwa, taman nasional taman hutan raya dan taman wisata alam. Peraturan ini merupakan pentunjuk teknis yang diamanatkan dalam peraturan pengelolaan kawasan konservasi di Indonesia dan Undang-undang No 5 Tahun 1990 ten KSDAE.

Dalam Pelaksanaan kegiatan izin pemanfaatan air dan energi air di kawasan taman nasional dari hasil penelitian lapangan yang menjadi kendala dalam penerapan izin pemanfaatan air dan energi air oleh pemerintah dalam hal ini Kementerian Lingkungan Hidup dan Kehutanan, khusunya Balai Besar Tman Nasional Kerinci Seblat sebagai berikut :

a. Kurangnya sosioalisasi peraturan izin pemanfaatan air dan energi air sehingga masih kurangnya pemohon dalam hal Pemanfaatan air dan energi air untuk non Komersil karena baru satu lembaga atau instansi yaitu SPN POLDA Bengkulu yang memanfaatkan air dalam kawasan TNKS. Dilapangan dimungkinkan 
diketemukan juga kelompok masyarakat yang memafaatkan air dari kawasan taman nasional kerinci seblat karena hal ini belum pernah dilakukan pendataan secara komperhensif.

b. Tidak adanya koordinasi dengan pemerintah daerah setempat menyebabkan terjadinya Permohonan izin dua pintu terhadap Objek atau lokasi yang sama yang pemohonan pertama izin melalui Pemerintah Daerah (Kabupaten Pesisir Selatan) dan Pemohonan Kedua izin melalui Kementerian LHK (Balai Besar TNKS). Sehingga terjadinya konflik sampai sekarang dalam tahap penyelesaian.

c. Tidak singkronya dengan peraturan yang terkait, artinya seperti peraturan lain yang menjadi dasar dalam pelaksanan pemberian izin. Salah satunya Izin lingkungan juga menjadi dasar dalam syarat administrasi izin pemanfaatan air dan energi air di Taman Nasional.

d. Adanya ketidak jelasan tata waktu khususnya dalam proses administrasi dan persyaratan teknis, Dalam hal izin pemanfaatan air secara komersil, prosedur persyaratan pertimbangan teknis dari kegaitan survey sampai dikeluarkannya pertimbangan teknis untuk memperoleh persetujuan prinsip dari Menteri, tata waktu belum diatur sehingga banyaknya permohonan izin yang staknan menyebabkan hilangnya kesempatan pemohon lain yang mempunyai kepentingan yang sama untuk pengurusan izin tersebut diobjek/ lokasi yang sama.

Adapun fungsi perizinan yaitu sebagai fungsi penertib dan fungsi pengaturan. Sebagai fungsi penertib, dimaksudkan agar izin atau setiap izin atau tempat-tempat usaha, bangunan dan bentuk kegiatan masyarakat lain tidak bertentangan satu sama lain, sehingga ketertiban dalam setiap segi kehidupan masyarakat dapat terwujud. Sebagai Fungsi pengatur dimaksud agar perizinan yang ada dilaksakan sesuai peruntukannya, sehingga terdapat penyalahgunaan izin yang telah diberikan, dengan kata lain fungsi pengaturan ini dapat disebut fungsi yang dimiliki oleh pemerintah sehingga menjamin dari segi teknis maupun dari segi kepastian hukum.

Secara umum tujuan dan fungsi pemberian izin adalah untuk pengendalian aktifitas pemerintah dan masyarakatan atau badan hukum dalam hal-hal tertentu 
dimana ketentuannya berisi pedoman-pedoman yang harus dilaksanakan oleh baik yang berkepentingan ataupun oleh pejabat yang berwenang. Dilihat dari sisi pemerintahan pemberian izin bertujuan untuk melaksanakan peraturan dan sebagai sumber pendapatan sedangkan dari sisi masyarakat yaitu adanya kepastian hukum dan kepastian hak dan untuk memudahkan mendapat fasilitas. Berangkat dari hambatan dan problem diperlukan solusi dalam pemanfaatan air dan energi air di taman nasional kerinci seblat antara lain :

a. Perlunya sosialisasi pemanfaatan air dan energi air kepada masyarakat, Instansi, lembaga perusahaan dan para pihak di sekitar kawasan TNKS

b. Perlunya koordinasi yang baik antara pihak Balai Basar Taman Nasional Kerinci Seblat dengan pihak Pemerintah daerah dalam penggelolaan kawasan konservasi khususnya pemanfaatan air dizona pemanfaatan taman nasional.

c. Perlunya singkronisasi dengan aturan izin terkait yaitu izin lingkungan dalam mejudkanan pembangunan yang berwawasan lingkungan ,tidak ada masalah perizinan sejauh ada kelengkapan syarat dan administrasi yang dipenuhi pemohon serta instansi bekerja sesuai dengan rule-nya. Walau demikian Pemerintah khususnya Balai Besar Taman Nasional Kerinci Seblat tetap mengambil kebijakan umum tentang pemanfaatan air dan energi air di taman nasional harus ada keseimbangan antara kepentingan ekonomi dan pelestarian fungsi kawasan konservasi dan lingkungan hidup.

d. Perlunya pengawasan, evaluasi dan pembinaan, baik dalam proses maupun pengawasan terhadap izin yang sudah dikeluarkan. pihak Balai Besar TNKS melakukan evaluasi dalam tahun 2017 ini dan masih dalam proses kegiatan evaluasi. Sampai saat ini belum adanya dikeluarkan sanksi administrasi kepada pemegang izin non komersil dan sanksi administrasi dari Dirjen untuk izin komersil pemegang IUPA (Izin Usaha Pemanfaatan Air) dan IUPEA (Izin Usaha Pemanfaatan Energi Air).

Peranan lingkungan hidup sebagai asset bangsa dan negara sangat penting sehingga diperlukan suatu pendekatan yang bijak dalam pengelolaannya. Pendekatan tersebut berkaitan pula karena lingkungan hidup sangat bersentuhan langsung dengan aktivitas pembangunan. Oleh karena itu begitu pentingnya 
lingkungan hidup, maka setiap rencana usaha dan atau kegiatan yang dapat menimbulkan dampak kerusakan terhadap lingkungan hidup, wajib memiliki Analisis Mengenai Dampak Lingkungan Hidup (AMDAL). (Supriadi, 2008:191)

\section{Simpulan}

1. Penerapan kebijakan peraturan izin pemanfaatan air dan energi air ditaman nasional telah dilaksanakan sesuai dengan peraturan dan perundang-undangan, untuk pemanfaatan air secara non komersil pihak Balai Besar TNKS sebagai subjek atau pemberi izin Pemanfaatan air dan energi air, pemberian izin dilakukan dengan cermat serta memperhitungkan kepentingan lingkungan agar tidak mengakibatkan terganggunya keseimbangan ekologis yang sulit dipulihkan. Sehingga pemberian izin pemanfaatan Air dan Energi Air di Taman Nasioanl juga memperhatikan perizinan lingkungan karena merupakan kebijakan lingkungan, yang paling penting agar dapat mendukung upaya peningkatan kesejahteraan masyarakat dan mutu kehidupan manusia serta mewujudkan pembangunan yang berwawasan lingkungan.

2. Kendala dalam penerapan kebijakan peraturan izin pemanfaatan air dan energi air di taman nasional kerinci Seblat. Pertama, kurangnya sosialisasi tentang pemanfaatan air dan energi air secara non komersil membuat permohonan izin pemanfaatan air sampai sekarang baru satu instasi yang telah di keluarkan izin pemanfaatan air (IPA). Kedua, Kurangnya koordinasi dengan pemerintah daerah dalam proses perizinan, karena masih banyak perizinanan lain yang berkaitan dengan izin pemanfaatan air dan energi air yang melibatkan pemerintah daerah. Ketiga, tidak sinkronnya izin pemanfaatan air dengan perizinan lain yaitu izin lingkungan baik Amdal dan UKL-UPL. Keempat, Perlunya tata waktu yang jelas dalam dalam persyaratan pertimbangan teknis dalam izin usaha pemanfaatan air dan energi air, sebagai salah satu syarat dalam perizinan (IUPA dan IUPEA), wewenang pemberian izin tetap dilakukan oleh Menteri Lingkungan Hidup dan Kehutanan. 


\section{E. Saran}

Pihak Balai Besar TNKS perlu melakukan sosialisasi tentang pemanfaatan air dan energi air khususnya pemanfaatan non komersil kepada masyarakat, instansi, atau lembaga sosial di sekitar kawasan taman nasional karena kurangnya pemahaman masyarakat dan mengindari pemanfaatan air dan energi air yang illegal atau tanpa izin serta supaya permohonan untuk pemanfaatan air dan energi air bertambah, karena potensi pemanfaatan air di TNKS sangat besar. Kepada pihak Pemerintah Cq. Kemeterian LHK perlu melakukan singkronisasi dengan merevisi Peraturan Menteri Kehutanan No. P.64/Menhut-II/2013, dalan hal pemanfaatan air dan energi air yang komersil setiap izin usaha/dan atau kegiatan harus mempunyai Izin Lingkungan yaitu AMDAL dan UKL-UPL, jadi tidak hanya di batasi UKLUPL tetapi seharusnya didasarkan pada Peraturan Pemerintah No. 27 tahun 2012 Tentang Izin Lingkungan. Dan perlunya pengawasan, evaluasi dan pembinaan minimal satu tahun sekali sesuai dengan amanat peraturan perundang-undangan.

\section{DAFTAR PUSTAKA}

\section{Buku- Buku.}

Adrian Sutedi. 2011. Hukum Perizinan Dalam Sektor Pelayanan Publik. Jakarta; Sinar Grafika.

Alam Setia Zain. 1998. Aspek Pembinaan Hutan dan Stratifikasi Hutan Rakyat. Jakarta; Rineka Cipta.

Christina Voight. 2009. Sustainable development as A Principal of International Law: resolving Conflicts Between Climate Measure and WTO Law. Laiden; Martinus Nijhoff Publishers.

Esmi Warrasih. 2005. Pranata Hukum: Sebuah Telaah Sosiologis. Semarang; Suryadaru Utama.

Joko Widodo. 2009. Analisis Kebijakan Publik; Konsep dan Aplikasi Analisis Proses Kebijakan Publik. Malang; Bayumedia Publishing.

N.M, Splet\&J.B.J. MtenBerge. 1993. Pengantar hukum perizinan, Surabaya; Yuridika.

Salim H.S dan Erlis Septina. 2013. Penerapan Teori Hukum Pada Penelitian Tesis dan Disertasi. Cetakan I. Jakarta; Rajawali Pers. 
Syahrul Machmud. 2012. Penegakan Hukum Lingkungan; Menegakan Hukum administrasi, Hukum Perdata; Hukum Pidana Menurut Undang-Undang No. 32 Tahun 2009. Yogyakarta; Graha Ilmu.

Sjachran Basah.1995. Pencabuatan Izin Salah Satu Sanksi Hukum Administrasi,Makalah pada Penataran Hukum Administrasi dan Lingkungan. Surabaya di Fakultas Hukum Unair.

Samsul wahidin. 2014. Dimensi Hukum Perlindungan dan Pengelolaan Lingkungan Hidup. Yogyakarta; Pusataka Pelajar.

Soetandyo Wignjosoebroto. 2013. Pergeseran Paradikma dalam kajian-kajian Sosial dan Hukum. Malang; Setara Press.

Supriadi. 2008. Hukum Lingkungan di Indonesia, Sebuah Pengantar. Jakarta; Sinar Grafika.

\section{Jurnal.}

David Thomas, Mercy Kariuki, Chris Magero and Albert Schenk. 2016. Local People and Goverment Working Together to Manage Natural Resources, Lessons from Lake Victoria Basin, Birdlife Africa, Kenya.

Faiqotul Falah. 2013. Kajian Efektifitas Pengelolaan Kolaboratif Taman Nasional Kutai. Jurnal Analisis Kebijakan Kehutanan Vol. 10. No. 1 April 2013.

Henry Bastaman. 2015. Isu dan Kebijakan Lingkungan Hidup di Indonesia, Jurnal Prosiding Seminar Nasional Biologi Lingkungan dan Pembelajaran, UIN Syarif Hidayatullah Jakarta, 24 Oktober 2015.

Rhiti dan Pudyatmoko. 2016.Kebijakan Perizinan Lingkungan Hidup di Yogyakarta, Jurnal Mimbar Hukum Volume 28, Nomor 2 Juni 2016.

\section{Peraturan Perundang - Undangan.}

Undang-Undang No. 51990 Tahun tentang Konservasi Sumber Daya Alam Hayati dan Ekosistemnyaa.

Undang-Undang No. 32 Tahun 2009 Tentang Perlindungan dan Pengelolaan Lingkungan Hidup.

Peraturan Pemerintah No. 28 Tahun 2011 Tentang Pengelolaan Kawasan Suaka Alam dan Kawasan Pelestarian Alam.

Peraturan Pemerintah No. 27 tahun 2012 Tentang Izin Lingkungan.

Peraturan Menteri Negara Lingkungan Hidup Nomor 05 Tahun 2012 Tentang Jenis rencana Usaha dan atau kegiatan yang wajib memiliki AMDAL. 
Peraturan Menteri Lingkungan Hidup Nomor 13 Tahun 2010 Tentang UKL-UPL dan SPPL.

Peraturan Menteri Kehutanan No. P.64/Menhut-II/2013 Tentang Pemanfatan Air dan Energi Air di Suaka Margasatwa, Taman Nasional, Taman Hutan Raya dan Taman Wisata Alam.

\section{Artikel Dalam Format Elektronik.}

Direktorat Pemanfaatan Jasa Lingkungan Hutan Konservasi KSDAE Kemenlhk, http://ekowisata.org/perijinan/pemanfaat-air/ diakses Pada Tanggal 4 September 2017, Jam 10.45 WIB.

TFCA Sumatera http://tfcasumatera.org/taman-nasional-kerinci-seblat-riwayatmu-ini/ diakses hari Senin Tanggal 4 September 2017 Jam 10.15 WIB.

Dirjen KSDAE http://ksdae.menlhk.go.id/berita/450/penandatanganan-notakesepahaman-tentang-pengamanan-dan-perlindungan-kawasan-tn-kerinciseblat-dengan-empat-polda.html. Diakses Tanggal 4 Septembe 2017 Jam 11.20 WIB.

Kemen.LHK, http://www.menlhk.go.id/berita-129-dataset-lingkungan-hidup-dankehutanan.html Laporan Statistik BBTNKS 2016. diakses Tanggal 8 September 2017 Jam 11.15 WIB. 